\title{
16 anos da Lei de Biossegurança (Lei n. 11.105/2005): a utilização de células-tronco embrionárias para fins de pesquisa e terapia e o status moral do embrião pré- implantatório
}

\author{
16 years of the Biosafety Law (Law n. 11.105/2005): use of stem cells for reasearch and \\ therapy purposes and the moral status of the preimplantation embryo
}

\author{
Gisele Mendes de Carvalho* \\ Vítor de Souza Ishikawa**
}

\begin{abstract}
REFERÊNCIA
CARVALHO, Gisele Mendes; ISHIKAWA, Vítor de Souza. 16 anos da Lei de Biossegurança (Lei n. 11.105/2005): a utilização de células-tronco embrionárias para fins de pesquisa e terapia e o status moral do embrião pré-implantatório. Revista da Faculdade de Direito da UFRGS, Porto Alegre, n. 47, p. 133-154, dez. 2021. DOI: https://doi.org/10.22456/0104-6594.112353.
\end{abstract}

\section{RESUMO}

A Lei n. 11.105/2005 tornou permitida a utilização de células-tronco embrionárias para fins de pesquisa e terapia, desde que cumpridas determinadas condições, conforme dispõe seu art. $5^{\circ}$, I e II. Coube investigar se o embrião pré-implantatório goza de status moral de pessoa humana, se se classifica como coisa (patrimônio) ou tão somente como um ser integrante da espécie humana, merecendo ou não, desde sua concepção, tutela jurídica. Utilizou-se o método de abordagem dedutivo, com análise da legislação e de pesquisa bibliográfica. Os resultados concluem que, embora o embrião pré-implantatório não se classifique como "coisa", uma análise ontoaxiológica afasta um suposto status de pessoa humana, não havendo violação a seus "direitos" em pesquisas que envolvam o uso de células-tronco embrionárias.

\section{PALAVRAS-CHAVE}

Células-tronco embrionárias. Lei de Biossegurança. ADC 3.510. Embrião pré-implantatório.

\begin{abstract}
Law n. 11.105/2005 allowed the use of embryonic stem cells in researches and in therapy programs, as long as certains conditions are fulfilled, as determined by the art. $5^{\circ}$, I and II. It is necessary to investigate whether the preimplantation embryo holds the moral status of a human being, if it is classified as a thing (patrimony) or just as a member of the human species, deserving or not, from its conception, legal protection. This research is based on a method of deductive approach, promoting the analysis of legislation and bibliographic research. The results conclude that, although the preimplantation embryo is not classified as a "thing", an ontoaxiological analysis rejects a supposed status of a human person, resulting in no violation of their "rights" in research involving the use of embryonic stem cells.
\end{abstract}

\section{KEYWORDS}

Embryonic stem cells. Biosafety law. ADI 3.510. Preimplantation embryo.

\section{SUMÁRIO}

1. Introdução. 2. A Lei de Biossegurança (Lei n. ${ }^{\circ}$ 11.105/2005) e a liberação condicionada do uso de célulastronco. 3. O embrião pré-implantatório e o direito constitucional à vida. 4. Análise ontoaxiológica do embrião pré-implantatório: a abordagem genético-desenvolvimentista. 5. Ação Direta de Inconstitucionalidade 3.510: a decisão do Supremo Tribunal Federal quanto ao uso de células-tronco embrionárias. 6. Conclusão. Referências. Dados da publicação.

*Professora associada de Direito Penal, Departamento de Direito Público. Mestre em Direito Penal pela Universidade Estadual de Maringá. Doutora e pós-doutora em Direito Penal pela Universidade de Zaragoza.

**Graduando em Direito. 


\section{INTRODUÇÃO}

As experiências com células-tronco embrionárias humanas, iniciadas a partir dos experimentos do embriologista James Thomson, na década de 1990, projetam horizontes positivos quanto ao tratamento e à cura de diversas doenças, como o diabetes e o mal de Parkinson. ${ }^{1}$ É que as células-tronco constituem um tipo único de célula por possuir duas propriedades que as distinguem: sua capacidade de dar origem a outros tipos de células, como células nervosas, e de renovar a si mesmas. ${ }^{2}$

As células-tronco embrionárias, encontradas na bainha interna do embrião, entretanto, destacam-se por sua pluripotência, ou seja, pela capacidade de originar qualquer célula no organismo - nos últimos anos, cientistas conseguiram obter células germinais de célulastronco embrionárias, possibilitando alterações genéticas em linha germinal de maneira mais controlada e segura e expandindo as perspectivas da engenharia genética humana. ${ }^{3}$

Ocorre que, a fim de ter acesso às células-tronco - e, assim, promover o desenvolvimento científico e a pesquisa com fins terapêuticos - o embrião pré-implantatório acaba por ser destruído. Se se considerar que a fecundação inicia uma vida humana e que o embrião humano pré-implantatório identifica-se com um ser humano em potencial, ostentando status moral de pessoa humana, sua aniquilação traduz-se como uma violação ao direito à vida. Ou seja, haveria não só uma exigência ético-legal da tutela do embrião humano préimplantatório como igualmente a proibição das pesquisas que utilizam células-tronco embrionárias.

Os avanços da biotecnologia trouxeram a necessidade de novas abordagens éticas, dado que possibilitaram situações e questões limítrofes ainda não previstas por normas ético-sociais ou legais. Luiz Régis Prado assinala que "o Direito, enquanto mecanismo regulador de condutas, encontra-se ligado indissoluvelmente às transformações humanas e socioculturais" ${ }^{4}$. A

\footnotetext{
${ }^{1}$ MUKHERJEE, Siddhartha. $O$ gene: uma história íntima. Tradução: Laura Teixeira Motta. São Paulo: Companhia das Letras, 2016, p. 545.

${ }^{2}$ Ibidem, p. 491.

${ }^{3}$ Ibidem, p. 552-553. Sobre isso, Stella Maris Martíneza diferencia engenharia genética e manipulação genética: "la ingeniería genética comprende la totalidad de las técnicas dirigidas a alterar o modificar el caudal hereditario de alguna especie, ya sea con el fin de superar enfermedades de origen genético (terapia genética) o con el objeto de producir modificaciones e transformaciones con finalidad experimental, esto es, de lograr un individuo con características hasta ese momento inexistentes en la especie (manipulación genética)". MARTÍNEZ, Stella Maris. Ingeniería genética: el desafio actual de la bioética. Cuadernos de bioética, Buenos Aires, v. 1, n. 0, p. 79-86., out, 1996, p. 80.

${ }^{4}$ PRADO, Luiz Régis. Direito penal do ambiente: crimes ambientais (Lei 9.605/1998). 7. ed.. Rio de Janeiro: Forense, 2019, p. 351.
} 
permissão ou a proibição do uso de células-tronco embrionárias deve ser analisada com fulcro no direito à vida, na dignidade da pessoa humana e na liberdade de investigação e pesquisa científica, previstos na Constituição Federal de 1988, que servirão como referências interpretativas obrigatórias quanto à delimitação de limites legais.

Considerando a dignidade da pessoa humana não só como fundamento do Estado Democrático de Direito, como estabelece o art. $1^{\mathrm{o}}$, III, da Constituição Federal ${ }^{5}$, como também o pilar axiológico que sustenta o ordenamento jurídico, caracterizando-se como valor, princípio e regra ${ }^{6}$, rejeita-se transformar a pessoa humana em meio, dado que sua dignidade intrínseca tão somente permite tratá-la como fim. Nesse sentido, Ferrando Mantovani assevera que o cientificamente possível só é lícito se for 'com' e 'para' a pessoa humana. ${ }^{7}$

Busca-se, com isso, distinguir as zonas do lícito e do ilícito e identificar quais práticas incompatibilizam-se com o conteúdo dos direitos e garantias fundamentais previstos na Constituição Federal. Para fins deste artigo, a análise limitar-se-á à (suposta) ofensa ao direito à vida e à dignidade do embrião humano destruído para fins de pesquisa e terapia com células-tronco embrionárias.

Cabe, dessa forma, analisar de que modo o ordenamento jurídico brasileiro trata da matéria, conforme a Lei de Biossegurança, Lei n. 11.105/2005. Em seguida, é necessário identificar se o embrião humano in vitro goza de status moral de pessoa humana ou não, a fim de avaliar a exigência de tutela jurídica e a conseguinte proibição ou permissão de experimentos que utilizam células-tronco embrionárias.

\section{A LEI DE BIOSSEGURANÇA (LEI N. ${ }^{\circ}$ 11.105/2005) E A LIBERAÇÃO CONDICIONADA DO USO DE CÉLULAS-TRONCO EMBRIONÁRIAS}

A Lei 11.105/2005, conhecida como Lei de Biossegurança, expressamente revogou a Lei 8.974/95, que previa como crime a produção, armazenamento ou manipulação de

\footnotetext{
5 BRASIL. Constituição da República Federativa do Brasil, de 1988. Disponível em <http://www.planalto.gov.br/ccivil_03/constituicao/constituicao.htm>. Acesso em: 18 mar. 2021.

6 "Valor porque representa o valor base e pré-constitucional sobre o qual se constrói o estado democrático de direito. Princípio porque se trata de um valor fundamental convertido constitucionalmente em mandado de optimização e fundamento normativo para os direitos fundamentais. Regra porque se apresenta como norma estrita, definida e descritiva e com pretensão de decibilidade no decorrer do ordenamento jurídico". SOUZA, Paulo Vinicius Sporleder de; CEOLIN, Guilherme; ALBRECHT, Diego. Dignidade da pessoa humana, pesquisa com células-tronco e proteção jurídico-penal do embrião in vitro. D’ÁVILA, Fábio Roberto et al (Org). Direito Penal e Constituição: diálogos entre Brasil e Portugal. Porto Alegre: Boutique Jurídica, 2018, p. 318.

${ }^{7}$ MANTOVANI, Ferrando. Manipulaciones genéticas, bienes jurídicos amenazados, sistemas de control y técnicas de tutela. Revista de derecho y genoma humano, Bilbao, n. 1, p. 93-119., jul./dez. 1994, p. 95.
} 
embriões humanos destinados a servirem como material biológico disponível, prevendo uma pena de seis a vinte anos. A Lei de 1995, porém, não mencionava células-tronco embrionárias.

O legislador, quando da elaboração da atual Lei de Biossegurança, por outro lado, atentou-se às perspectivas terapêuticas da pesquisa com células-tronco embrionárias. Com isso, o art. 5, caput, da Lei 11.105/2005, permitiu sua utilização, desde que extraídas de embriões humanos oriundos de técnicas de fertilização in vitro ${ }^{8} \mathrm{e}$ não utilizadas no procedimento.

Ou seja, buscou-se dar um destino louvável aos embriões que, produzidos com a finalidade de reprodução, acabavam crioconservados por se constituírem como "embriões excedentes" ou sobrantes. Com a permissão da Lei, embriões que antes eram descartados ou mantidos crioconservados indefinidamente destinam-se à pesquisa e à terapia, servindo como material para projetos que visam à cura e ao tratamento de males humanos.

Nem todos os embriões pré-implantatórios sobrantes, no entanto, podem ser utilizados. $\mathrm{O}$ art. $5^{\circ}$, I e II, limita a permissão a embriões inviáveis e a embriões com mais de 3 anos, quando da promulgação da Lei, ou, já congelados a partir dela, que atingirem 3 anos. ${ }^{9} \mathrm{O} \S 1^{\circ}$, do mesmo artigo, impõe ainda a necessidade do consentimento por parte dos genitores.

Por um lado, o critério da viabilidade justifica a destruição do embrião préimplantatório quando este perde sua função - sua capacidade de autodesenvolvimento e a resultante formação de uma vida independente. ${ }^{10}$ Quanto ao critério temporal, o legislador distingue embriões pré-implantatórios com base no tempo de crioconservação. Nesse sentido, cabe apontar um grave equívoco: embriões pré-implantatórios crioconservados após a promulgação da Lei, mesmo que alcançassem os três anos de congelamento, não poderiam ser destinados à pesquisa com células-tronco embrionárias. Não havendo razão para firmar como marco temporal a promulgação da Lei, já que ausente qualquer distinção axiológica entre um

\footnotetext{
${ }^{8}$ Trata-se de uma técnica de reprodução assistida em que, em laboratório, a fecundação ocorre na incubadora e, posteriormente, os embriões são transferidos ao útero da mulher. MALUF, Adriana Caldas do Rego Freitas Dabus. Curso de bioética e biodireito. 3. ed. São Paulo: Atlas, 2015, p. 199-200.

9 BRASIL. Lei n. 11.105, de 24 de março de 2005. Lei de Biossegurança. Disponível em: < http://www.planalto.gov.br/ccivil_03/_ato2004-2006/2005/lei/111105.htm>. Acesso em: 18 mar. 2021.

${ }^{10}$ CARVAlHO, Gisele Mendes de. Patrimônio genético e direito penal. Curitiba, Juruá, 2008, p. 190. Maria Helena Diniz assevera que embrião inviável vem a ser aquele que "teve seu desenvolvimento interrompido por ausência espontânea de clivagem após período superior de vinte e quatro horas, a partir da fertilização in vitro, ou alterações morfológicas que comprometam o seu pleno desenvolvimento". DINIZ, Maria Helena. O estado atual do biodireito. 10. ed. São Paulo: Saraiva, 2017, p. 647.
} 
embrião pré-implantatório crioconservado antes ou depois da promulgação da Lei, melhor seria, de imediato, a revogação deste critério. ${ }^{11}$

Finalmente, cabe esclarecer que consideramos mais correto o emprego do termo "embrião pré-implantatório" ao fazer referência àquele produzido em laboratório, seja a fim de servir como material direto a pesquisas, seja como parte de técnicas de reprodução assistida, com o objetivo de diferenciá-lo, ontológica e axiologicamente, do embrião que se desenvolve dentro do útero humano.

Outros autores preferem e/ou aceitam o termo "pré-embrião"12; ocorre, entretanto, que o prefixo "pre-" indica anterioridade, tempo passado. ${ }^{13}$ Como pontua Maria Helena Diniz, a fecundação resulta em um zigoto humano e, após subdivisões, em embrião humano, que goza de plena identidade genética, de forma que nada há antes dele, apenas células germinativas (espermatozoide e óvulo) ${ }^{14}$. Por isso, neste artigo, quando necessário, utilizaremos os termos "embrião pré-implantatório", "embrião in vitro" ou embrião "ex utero".

\section{O EMBRIÃO PRÉ-IMPLANTATÓRIO E O DIREITO CONSTITUCIONAL À}

\section{VIDA}

Albin Eser sintetiza o fundamento principal acerca da defesa da tutela do embrião préimplantatório: o embrião, concebido in vitro ou não, carrega em si acabada construção genética, constituindo um sujeito potencial dada sua completa potencialidade da pessoa. Não se poderia, logo, negar-lhe um estatuto moral, uma dignidade que exige tutela básica com vistas a prevenir abusos e agressões. ${ }^{15}$

Embora justifique a morte do embrião, quando inevitável e se a conquista de conhecimentos médico-científicos resultarem em benefícios à pessoa humana, Eser destaca

\footnotetext{
${ }^{11}$ CARVALHO, Gisele Mendes de. Patrimônio genético e direito penal. Curitiba, Juruá, 2008, p. 166-167.

${ }^{12}$ Como, por exemplo, Luiz Régis Prado. PRADO, Luiz Régis. Direito penal do ambiente: crimes ambientais (Lei 9.605/1998). 7. ed.. Rio de Janeiro: Forense, 2019, p. 370. Stella Maris Martínez, embora utilize o termo "pré-embrião", reconhece suas limitações e opta pelo emprego da expressão "substância embrionária humana". MARTÍNEZ, Stella Maris. Manipulação genética e direito penal. São Paulo: IBCCRIM / Complexo Jurídico Damásio de Jesus, 1998. v. 6. 300 p. (Monografias / IBCCRIM, 6), p. 94.

${ }^{13}$ BECHARA, Evanildo. Moderna gramática portuguesa. 38 ed. rev. ampl. Rio de Janeiro: Nova Fronteira, 2015, p. 385.

${ }^{14}$ DINIZ, Maria Helena. O estado atual do biodireito. 10. ed. São Paulo: Saraiva, 2017, p. 639. Bechara afirma, ainda, que nenhum manual de embriologia utiliza o termo "pré-embrião", rechaçando seu uso. BECHARA, Ana Elisa Liberatore Silva. Manipulação genética humana e direito penal. Porto Alegre: Zouk, 2007, p. 108.

15 ESER, Albin. Genética humana: aspectos jurídicos e sociopolíticos. Tradução de Pedro Caeiro. Revista Portuguesa de Ciência Criminal. Lisboa, ano 2., n. 1, p. 45-72, 1992, p. 63.
} 
que "se sacrifica a vida humana em benefício alheio", por meio da destruição direta da vida. ${ }^{16}$ Por fim, rejeita veementemente a criação pré-ordenada de embriões pré-implantatórios para fins de pesquisa, considerando-a a total instrumentalização da pessoa, enquanto uma atividade que "coisifica" uma vida humana. ${ }^{17}$ Romeo Casabona acompanha esse entendimento, incluindo qualquer investigação sobre o embrião na zona do ilícito por configurar a coisificação do embrião in vitro viável. ${ }^{18}$

Caminha no mesmo sentido Paulo Vinícius Sporleder de Souza quanto à afirmação de um status moral do embrião ex utero e a urgência do fortalecimento da ingerência estatal, pela via do Direito Penal, visando à sua tutela, enfatizando os casos em que a utilização do embrião pré-implantatório se dê com interesses puramente científicos, comerciais ou industriais, sem fins terapêuticos. ${ }^{19}$ Alerta o autor que a insuficiente proteção legal do embrião

in vitro torna-se preocupante na medida em que o ser humano pode ser rebaixado a mero objeto desvalioso, degradando-se por completo a sua condição humana como tal, atentando-se contra a sua dignidade. ${ }^{20}$

A permissão do art. $5^{\circ}$, caput, da Lei de Biossegurança acabaria, desse modo, por ofender a vida humana embrionária, por levar a consequências negativas quanto à dignidade humana do embrião pré-implantatório e por violar a dignidade reprodutiva humana. Isso porque, deturpando sua destinação natural - a reprodução e seu consequente autodesenvolvimento - a ciência e o mercado o instrumentalizariam ao buscar outros fins mediante sua destruição: quanto à primeira, em benefício de outras vidas, ao segundo, com

\footnotetext{
${ }^{16}$ Ibidem, p. 64.

${ }^{17}$ Ibidem, p. 64-65. Claus Roxin compartilha de igual compreensão, argumentando que o embrião se trata de uma vida humana em potencial, e merece, até certo ponto, a proteção e dignidade de um ser humano já nascido o que exclui, por conseguinte, a produção de embriões in vitro com o fim único de investigação, enquanto material de consumo. ROXIN, Claus. La protección de la vida humana mediante el derecho penal. In: BARJA DE QUIROGA, Jacobo López; ZUGALDÍA ESPINAR, José Miguel (Coords.). Dogmática y ley penal: libro homenaje a Enrique Bacigalupo. Madrid: Marcial Pons, 2004, p. 24.

${ }^{18}$ ROMEO CASABONA, Carlos María. Do gene ao direito: sobre as implicações jurídicas do conhecimento e intervenção no genoma humano. São Paulo: IBCCRIM - Instituto Brasileiro de Ciências Criminais, 1999. v. 9 , p. 259.

${ }^{19}$ SOUZA, Paulo Vinicius Sporleder de. Direito penal genético e a lei de biossegurança: Lei 11.105/2005: comentários sobre crimes envolvendo engenharia genética, clonagem, reprodução assistida, análise genômica e outras questões. Porto Alegre: Livraria do Advogado, 2007, p. 16.

${ }^{20}$ Ibidem, p. 16.
} 
vistas a sua comercialização e, assim, ao lucro, independente da destinação, que pode ser reprodutiva ou não. ${ }^{21}$

Como se verificou, tal posição se condiciona à demonstração de que o embrião préimplantatório vem a ser titular do direito à vida, previsto constitucionalmente no art. $5^{\circ}$, caput, da Constituição Federal. Em caso afirmativo, não haveria de se falar em pesquisas que envolvam células-tronco embrionárias, dado que estas acabam por provocar a destruição do embrião in vitro e, consequentemente, por ferir sua dignidade.

Nesse sentido, cabe apontar a dupla conceituação de dignidade da pessoa humana, fundamento do Estado Democrático de Direito, conforme art. $1^{\circ}$, III, da Constituição Federal de $1988 .{ }^{22}$ Em sentido positivo, a dignidade da pessoa humana vem a ser

\begin{abstract}
a qualidade intrínseca e distintiva reconhecida a cada ser humano que o faz merecedor do mesmo respeito e consideração por parte do Estado e da comunidade, implicando, neste sentido, um complexo de direitos e deveres fundamentais que assegurem a pessoa tanto contra todo e qualquer ato de cunho degradante e desumano como venham a lhe garantir as condições existenciais mínimas para uma vida saudável, além de propiciar e promover sua participação ativa e corresponsável nos destinos da própria existência e da vida em comunhão com os demais seres humanos, mediante o devido respeito aos demais seres que integram a rede da vida. $^{23}$
\end{abstract}

Por outro lado, Ingo Sarlet traz uma concepção negativa da dignidade da pessoa humana: não há consideração à dignidade da pessoa humana quando não se identificar o respeito à vida e à integridade física e moral do ser humano, nem houver garantia de condições mínimas a uma existência digna. ${ }^{24}$ Definir a existência ou não da titularidade do direito à vida do embrião pré-implantatório, portanto, revela a questão central do debate acerca das pesquisas com células-tronco embrionárias, tendo em vista a inafastabilidade da dignidade da pessoa humana em qualquer campo da vida.

José Afonso da Silva contempla o direito à vida como o direito à existência, a permanecer vivo, “de não ter interrompido o processo vital senão pela morte espontânea e

\footnotetext{
${ }^{21}$ SOUZA, Paulo Vinicius Sporleder de; CEOLIN, Guilherme; ALBRECHT, Diego. Dignidade da pessoa humana, pesquisa com células-tronco e proteção jurídico-penal do embrião in vitro. D’ÁVILA, Fábio Roberto et al (Org). Direito Penal e Constituição: diálogos entre Brasil e Portugal. Porto Alegre: Boutique Jurídica, 2018, p. 350. Ato contínuo, o autor defende a expansão da tutela penal, propondo a criação de crimes de "embrionicídio", tornaria delito a conduta de destruir embriões in vitro. SOUZA, Paulo Vinicius Sporleder de. Bem jurídico penal e engenharia genética humana: contributo para compreensão dos bens jurídicos supraindividuais. São Paulo: Revista dos Tribunais, 2004, p. 210.

22 BRASIL. Constituição da República Federativa do Brasil, de 1988. Disponível em <http://www.planalto.gov.br/ccivil_03/constituicao/constituicao.htm>. Acesso em: 18 mar. 2021.

${ }^{23}$ SARLET, Ingo Wolfgang. Dignidade da pessoa humana e Direitos Fundamentais na Constituição de 1988. 9. ed. Porto Alegre: Livraria do Advogado, 2011, p. 62-63.

${ }^{24}$ Ibidem, p. 62.
} 
inevitável”25. O autor percebe, entretanto, a vida além de seu sentido biológico, tratando-a em uma acepção biográfica, apontando sua riqueza significativa por sua dinamicidade, um fluir espontâneo e incessante. Quer dizer: aquele dotado de vida é indivíduo, enquanto algo que não se pode dividir, sob pena de deixar de ser, tratando o ser humano como pessoa. ${ }^{26}$

Sugerindo a indissociabilidade entre o direito à vida e o ser humano, singularizado por uma intrínseca e indisponível dignidade, Paulo Branco afirma a que "a todo ser humano deve ser reconhecida a titularidade do direito mais elementar de expressão dessa dignidade única o direito a existir" ${ }^{27}$. Por consequência, o elemento central do reconhecimento e da proteção da vida humana é a verificação de sua existência desde sua concepção, naturalmente ou in vitro, sem discriminação por etapas biológicas. ${ }^{28}$ Dito de outro modo, o único pressuposto do direito à vida é o pertencimento à espécie homo sapiens, individualidade por carga genética única e distinta. ${ }^{29}$

Concebendo o embrião pré-implantatório como merecedor de proteção de sua vida, integridade física e dignidade, em razão de sua potencialidade de pessoa humana a partir da fecundação, como garantiria o art. $2^{\mathrm{o}}$ do Código Civil ${ }^{30}$, Maria Helena Diniz conclui pela inconstitucionalidade do art. $5^{\circ}$ da Lei 11.105/2005 $5^{31}$. Em síntese, Diniz defende que o uso de células-tronco embrionárias sem finalidade terapêutica voltada à sua própria cura equivaleria a instrumentalizar o ser humano. ${ }^{32}$

As concepções referidas, portanto, seguem duas linhas de argumentação, ora figurandose apenas em uma, ora (equivocadamente) misturando-as: a compreensão do embrião como pessoa digna e titular do direito à vida quanto a um critério biológico ou com base em um conceito ético.

\footnotetext{
${ }^{25}$ SILVA, José Afonso. Curso de direito constitucional positivo. 40. ed., rev. e atual. São Paulo: Malheiros, 2017, p. 200.

${ }^{26}$ Ibidem, p. 199.

${ }^{27}$ MENDES, Gilmar Ferreira; BRANCO, Paulo Gustavo Gonet. Curso de direito constitucional. 9. ed. rev. e atual. São Paulo: Saraiva, 2014, p. 257.

${ }^{28}$ Ibidem, p. 258.

${ }^{29} \mathrm{E}$ conclui: "O indivíduo que se consubstancia da fusão de gametas humanos não é apenas potencialmente humano ou uma pessoa em potencial; é um ser humano, por pertencer à espécie humana. Por conta dessa sua essência humana, o ainda não nascido tem direito à vida como os já nascidos, até por imposição do principio da igual dignidade humana. $\mathrm{O}$ direito à vida tem na fecundação o seu termo inicial e na morte o seu termo final". Ibidem, p. 259

${ }^{30} \mathrm{O}$ Código Civil parece abrir espaço à teoria concepcionista, dispondo que a lei tutela os direitos da personalidade desde a concepção. Nesse sentido, argumentando pela consideração do embrião como pessoa, ver Riva, Batista e Breviglieri. RIVA, Léia Comar; BATISTA, Claudia Karina Ladeia; BREVIGLIERI, Etiene Maria Bosco. Os direitos fundamentais do embrião in vitro no Brasil: personalidade e herança. Status Libertatis, Paranaíba, v. 2, n. 2, p. 49-68, 2018.

${ }^{31}$ DINIZ, Maria Helena. O estado atual do biodireito. 10. ed. São Paulo: Saraiva, 2017, p. 664.

${ }^{32}$ Ibidem, p. 644.
} 
O primeiro critério figura como uma das três hipóteses de um conceito particular, ${ }^{33} \mathrm{em}$ que se estabelece um marco inicial para a existência da pessoa. Importando tão somente a ordem biológica, há uma humanização imediata: o momento em que espermatozoide encontra o óvulo. Com a fecundação, atesta-se a existência de um ser humano que merece tutela. ${ }^{34}$

A noção de pessoa potencial, por outro lado, caracteriza-se como uma concepção ética, enquanto um conceito inspirador, que não se esgota na biologia nem na filosofia, nem tratando de uma mera potencialidade ou considerando o embrião estritamente como pessoa. $\mathrm{O}$ acolhimento dessa concepção importa reconhecer como valor a plena e inerente potencialidade biológica do embrião de desenvolver-se até uma vida independente e a compreensão de "realidades culturais no âmago das quais esse ser humano se encaminha para o sujeito pessoal" 35 . Não se declara o embrião como algo que "seja", mas que "deva ser reconhecido" como pessoa humana potencial - afirmando-se, assim, sua classificação como pessoa, e não como coisa. ${ }^{36}$

Em apertada síntese, tratando o embrião pré-implantatório como pessoa, que ostenta uma dignidade intrínseca e titular do direito à vida, rejeitar-se-iam as técnicas, mesmo com finalidades terapêuticas, que resultassem em sua destruição, seja por uma perspectiva meramente biológica, ligada à fecundação e a individualidade genética, seja por uma perspectiva ética, de sua consideração enquanto pessoa potencial. Fazê-lo significaria tratar uma vida humana enquanto meio, não como fim, violando seu direito à vida e sua dignidade. Concluir-se-ia, portanto, pela incompatibilidade do art. $5^{\circ}$, da Lei de Biossegurança, com a Constituição Federal de 1988 (arts. 1, III, e 5º caput), levando à inconstitucionalidade daquele.

\footnotetext{
${ }^{33}$ Quais sejam, humanização imediata, que identifica na fecundação a consideração do embrião como pessoa; humanização diferida, que distingue etapas biológicas e juízos axiológicos, não compreendendo o embrião como indivíduo completo; e uma humanização com base na relacionalidade, geralmente fixando o momento do nascimento como referencial. DURAND, Guy. Introdução geral à bioética: história, conceitos e instrumentos. Tradução de Nicolás Nyimi Campanário. 5 ed. São Paulo: Centro Universitário São Camilo, Loyola, 2014, p. $295-296$

${ }^{34}$ Ibidem, p. 295.

${ }^{35}$ Ibidem, p. 296-298. Guy Durand, assim, assevera que "reconhecer no embrião uma dignidade que nos obriga ao respeito é ter preocupação com a potencialidade biológica que ele possui e, portanto, com as consequências de nossos atos sobre seu futuro bio-médico, preocupação com a representação antecipada da pessoa psicológica, social e moral cuja edificação já começou e, portanto, com as consequências de nossas escolhas sobre seu destino de sujeito humano".

${ }^{36}$ Ibidem, p. 298.
} 


\section{ANÁlise ONTOAXIOLÓGICA DO EMBRIÃO PRÉ-IMPLANTATÓRIO: A ABORDAGEM GENÉTICO-DESENVOLVIMENTISTA}

Ocorre, entretanto, que o Direito, ora conceituado como um meio de regular condutas que se vincula a concepções socioculturais, não pode renunciar a uma análise orientada por juízos axiológicos. A saber: não basta, meramente, basear-se em meros dados biológicos. $\mathrm{O}$ substrato ontológico - no caso, o embrião pré-implantatório e seu desenvolvimento natural em fases biológicas - serve tão somente enquanto o objeto a ser valorado juridicamente, por meio de uma análise ontoaxiológica. ${ }^{37}$

Como exemplo, o Código Penal sanciona com penas diferentes os crimes de aborto e homicídio - apesar de se tratarem de crimes contra a pessoa, o crime de aborto ofende o bem jurídico vida dependente ou intraulterina (a partir do da nidação, i. e., do $14^{\circ}$ dia de gestação) $^{38}$, enquanto o de homicídio, a vida independente ou extraulterina (a partir do início do parto) ${ }^{39}$. Sanciona-se, assim, o delito de homicídio simples (art. 121, caput, do Código Penal) com pena de reclusão de seis a vinte anos; o de autoaborto (art. 124, do Código Penal), de detenção, de um a três anos; de aborto provocado por terceiro sem o consentimento da gestante (art. 125, do Código Penal), de reclusão, de três a dez anos; e, por fím, de abordo provocado com o consentimento da gestante (art. 126, caput, do Código Penal), de reclusão, de um a quatro anos. ${ }^{40}$

Resta verdadeiro que, à medida que o ser humano em formação se desenvolve, "maior deve ser a importância (aspecto valorativo) que terá a vida que possui a potencialidade de em si mesma de dar lugar a um ser humano (aspecto ontológico)" ${ }^{41}$, levando a uma maior gravidade da punição por parte do Direito Penal, em consonância com o princípio da proporcionalidade. $^{42}$

\footnotetext{
${ }^{37}$ CARVALHO, Gisele Mendes de. Patrimônio genético e direito penal. Curitiba, Juruá, 2008, p. 180.

${ }^{38}$ PRADO, Luiz Regis; CARVALHO, Érika Mendes de; CARVALHO, Gisele Mendes de. Curso de direito penal brasileiro. 14. ed. rev. atual. e ampl. São Paulo: Revista dos Tribunais, 2015, p. 665.

${ }^{39}$ BITENCOURT, Cezar Roberto. Tratado de direito penal: parte especial 2: crimes contra a pessoa. 17. ed. rev., ampl. e atual. São Paulo: Saraiva, 2017, p. 54.

40 Brasil. Decreto-Lei n. 2.848, de 07 de dezembro de 1940. Código Penal. Disponível em: < http://www.planalto.gov.br/ccivil_03/decreto-lei/del2848compilado.htm>. Acesso em: 18 mar. 2021.

${ }^{41}$ CARVAlHO, Gisele Mendes de. Patrimônio genético e direito penal. Curitiba, Juruá, 2008, p. 181. Nesse sentido, Stella Maris Martínez aduz que "embora ninguém discuta que se trata do mesmo indivíduo, em distintas etapas de seu desenvolvimento, resultando coerente admitir que o fenômeno se configura num desses saltos qualitativos relevantes”. MARTÍNEZ, Stella Maris. Manipulação genética e direito penal. São Paulo: IBCCRIM / Complexo Jurídico Damásio de Jesus, 1998. v. 6. 300 p. (Monografias / IBCCRIM, 6), p. 89.

${ }^{42}$ Quer dizer, uma ponderação entre a conduta proibida e a pena cominada, à luz do bem jurídico-penal atingido e de sua importância e da gravidade da conduta que o ofende. MARTINELLI, João Paulo Orsini; DE BEM,
} 
Os defensores da teoria genético-desenvolvimentista estabelecem como referencial axiológica a nidação: estágio biológico, após as duas primeiras semanas de vida, em que o embrião se fixa no útero materno. ${ }^{43}$ Até este momento, há tão somente uma mera existência biológica carente de unicidade (ser uno e indivisível) e de unidade (ser único e inconfundível), pois há ainda chances de ou ser dividir, formando gêmeos univitelinos, ou de se fundir com outro embrião, originando uma "quimera humana". 44

Outro aspecto relevante vem a ser a relação de alteridade com os genitores: com a nidação, o embrião pré-implantatório possui especial significado à medida que é compreendido como um ser humano uno e único em constante formação dentro do útero da mulher, ${ }^{45}$ adquirindo transcendência. ${ }^{46}$ Considerando a nidação um momento em que se efetiva um salto qualitativo no desenvolvimento do ser humano, ${ }^{47}$ há de se negar qualquer status moral do embrião pré-implantatório e, por consequência, sua tutela por si mesmo.

A teoria genético-desenvolvimentista se configura como uma teoria de humanização diferida, em que se estabelece um critério particular para a existência da pessoa. ${ }^{48}$ Adverte-se que a vida se inicia com a fecundação, sem dúvidas. Ocorre, entretanto, que até a nidação o substrato ontológico, que se exaure em uma mera realidade biológica, carece de valor que justifique uma dignidade merecedora de tutela. Daí haver uma distinção axiológica significativa entre o embrião pré-implantatório e o nascituro que ultrapassou a fase da nidação, fenômeno determinante à identificação precisa da proteção jurídica a ser aplicável e do âmbito de força e de tutela dos direitos fundamentais.

Leonardo Schmitt. Lições fundamentais de direito penal: parte geral. 4. ed. São Paulo: Saraiva, 2019, p. 196. Na mesma trilha caminha Luiz Régis Prado. PRADO, Luiz Régis. Direito penal do ambiente: crimes ambientais (Lei 9.605/1998). 7. ed.. Rio de Janeiro: Forense, 2019, p. 362.

${ }^{43}$ CARVALHO, Gisele Mendes de. Patrimônio genético e direito penal. Curitiba, Juruá, 2008, p. 184.

${ }^{44}$ Ibidem.

${ }^{45}$ Ibidem, p. 185.

${ }^{46}$ MARTÍNEZ, Stella Maris. Manipulação genética e direito penal. São Paulo: IBCCRIM / Complexo Jurídico Damásio de Jesus, 1998. v. 6. 300 p. (Monografias / IBCCRIM, 6), p. 85.

47 “Tratando-se de células em fase absolutamente inicial de existência, não há como lhes conferir o mesmo valor moral conferido a uma pessoa adulta, com personalidade, relacionamentos e história de vida e potencialidades. Tampouco há como reconhecer uma dignidade implícita de algo que jamais terá a vida realizada, sequer a vida intraulterina." VIEIRA, Oscar Vilhena; ALMEIDA, Eloísa Machado de. Constitucionalidade das pesquisas com células-tronco embrionárias. Revista da Defensoria Pública, São Paulo, v. 2, n. 1, p. 257-263., jul./dez. 2008, p. 261.

${ }^{48}$ DURAND, Guy. Introdução geral à bioética: história, conceitos e instrumentos. Tradução de Nicolás Nyimi Campanário. 5 ed. São Paulo: Centro Universitário São Camilo, Loyola, 2014, p. 294-296. 
É que a dignidade da pessoa humana, conforme as concepções positiva e negativa de Ingo Sarlet, parte de uma abordagem personalista. ${ }^{49} \mathrm{O}$ embrião anterior à nidação - com ênfase ao embrião pré-implantatório, produzido em laboratório -, caracteriza-se como ser humano, de forma a não ser coisa, patrimônio. ${ }^{50}$ Entretanto, não vem a ser pessoa, no sentido delineado por Peter Singer, baseado nos apontamentos de John Locke e Joseph Fletcher: enquanto "ser humano" designa aquele que pertence à espécie Homo sapiens; "pessoa", por outro lado, compreende aquele que é portador de "indicadores de humanidade" 51 , de capacidade de razão e reflexão e de ter interesses, de senciência ${ }^{52}$ e de individualidade ${ }^{53}-$ de forma que o embrião pré-implantatório não possui nenhum desses atributos.

Sobre isso, a Convenção Americana de Direitos Humanos (Pacto de São José da Costa Rica) determina que pessoa é todo ser humano (art. $2^{\circ}$ ) e, em seu art. $4^{\circ}$, inc. 1 , vincula o direito da pessoa a ter sua vida respeitada ao momento da concepção. ${ }^{54}$ Poder-se-ia argumentar, logo, que a Convenção protege a vida humana desde a concepção, indistintamente. Entretanto, a Corte Interamericana de Direitos Humanos decidiu, por maioria dos votos, que o embrião só se constitui como pessoa após sua implantação no útero, destituindo o embrião pré-implantatório de estatuto moral. ${ }^{55}$

Dessa forma, caberia a tutela jurídico-penal não de um bem jurídico-penal individual, cujo objeto material se identificaria com o embrião humano pré-implantatório, mas de um bem jurídico transindividual; por exemplo, na hipótese de manipulação de células-tronco embrionárias a fim de provocar uma alteração genética que atingisse a linha germinal de determinado indivíduo, o que constitui o delito do art. 25 da Lei de Biossegurança. ${ }^{56}$ Daí se

\footnotetext{
${ }^{49}$ CARVALHO, Gisele Mendes de. Patrimônio genético e direito penal. Curitiba, Juruá, 2008, p. 178.

${ }^{50}$ MARTÍNEZ, Stella Maris. Manipulação genética e direito penal. São Paulo: IBCCRIM / Complexo Jurídico Damásio de Jesus, 1998. v. 6. 300 p. (Monografias / IBCCRIM, 6), p. 111.

${ }^{51}$ Quais sejam, consciência de si, autocontrole, senso de futuro e passado, capacidade de relacionar-se com os outros, preocupação com os outros, comunicação e curiosidade. SINGER, Peter. Ética prática. Tradução de Jefferson Luiz Camargo. $3^{\circ}$ ed. São Paulo: Martins Fontes, 2002, p. 96.

${ }^{52}$ Ibidem, p. 96-97.

${ }^{53}$ Ibidem, p. 166.

${ }^{54}$ SOUZA, Paulo Vinicius Sporleder de; CEOLIN, Guilherme; ALBRECHT, Diego. Dignidade da pessoa humana, pesquisa com células-tronco e proteção jurídico-penal do embrião in vitro. D’ÁVILA, Fábio Roberto et al (Org). Direito Penal e Constituição: diálogos entre Brasil e Portugal. Porto Alegre: Boutique Jurídica, 2018, p. 328-329.

${ }^{55}$ CORTE INTERAMERICANA DE DERECHOS HUMANOS. Caso Artavia Murillo y otros (Fecundación in vitro) Vs. Costa Rica, p. 264. Sentença de 28 de novembro de 2012. Disponível em http://www.corteidh.or.cr/docs/casos/articulos/seriec_257_por.pdf, acesso em 30 de setembro de 2019.

56 À conduta de praticar engenharia genética humana em célula germinal, zigoto humano ou embrião humano, o art. 25 da Lei 11.105/2005 prevê a pena de 1 a 4 anos de reclusão, e multa. BRASIL. Lei n. 11.105, de 24 de março de 2005. Lei de Biossegurança. Disponível em: < http://www.planalto.gov.br/ccivil_03/_ato20042006/2005/lei/l11105.htm>. Acesso em: 18 mar. 2021.
} 
extrai a ilegitimidade do art. 24, da mesma Lei, que criminaliza o uso de embriões em desacordo com os critérios do art. $5^{\circ}$, já apresentados, sob pena de 1 a 3 anos de detenção, e multa.

Em síntese, considerando a análise ontoaxiológica a mais adequada para enfrentar a questão do status moral do embrião pré-implantatório, conclui-se por sua carência de suficiente dignidade que lhe confira o caráter de pessoa. Não se trata, vale dizer, de tratá-lo como um nada jurídico ${ }^{57}$ ou uma coisa, patrimônio; enquanto ser humano, o embrião in vitro impõe especial respeito, oriundo de "uma valorização mais ampla da vida como dádiva que pede nosso respeito e restringe nosso uso" ${ }^{\text {58 }}$. Daí se fundamenta a redução das hipóteses legítimas de criação e/ou utilização de embriões pré-implantatórios à finalidade de terapia, que se constitui como desdobramento do direito à saúde e que reverbera na possibilidade de uma vida digna a pessoas que sofrem de males graves e incuráveis, resultado de uma relativização de sua proteção jurídica.

Extraem-se dessa afirmação, portanto, quatro consequências: a ausência de incompatibilidade entre a destruição de embriões pré-implantatórios com fins de pesquisa e terapia e os direitos e garantias fundamentais previstos na Constituição Federal de 1988; a compreensão de que não há qualquer conflito ético na atividade de produção de embriões pré-implantatórios com o único fim de pesquisa e terapia; a limitação do uso de embriões pré-implantatórios a fins de reprodução, de pesquisa e de terapia, afastando seu uso para fins cosméticos, bélicos ou comerciais; a revogação das condições do art. $5^{\circ}$, I e II, da Lei de Biossegurança.

Quanto à primeira conclusão, Luís Roberto Barroso destaca que

a extração das células-tronco ocorre (I) antes do início da formação do sistema nervoso, quando o embrião é apenas um conjunto de células não diferenciadas; (II) antes da nidação, i.e., da fixação do embrião no útero; (III) antes de qualquer viabilidade de vida extra-uterina e, até mesmo, antes que se possa considerá-lo um ser individualizado. ${ }^{59}$

\footnotetext{
${ }^{57}$ Como, por exemplo, supõe Bechara. BECHARA, Ana Elisa Liberatore Silva. Manipulação genética humana e direito penal. Porto Alegre: Zouk, 2007, p. 111.

${ }^{58}$ SANDEL, Michael J. Contra a perfeição: ética na era da engenharia genética. Tradução Ana Carolina Mesquita. Rio de Janeiro: Civilização Brasileira, 2013, p. 133. Cabe a advertencia de Arthur Kaufmann: "No es posible determinar com los medios de lo conocimiento científico si un embrión posee individualidad y dignidad personal (em absoluto un alma inmortal). Pero, de otra parte, también el supuesto especulativo de que el embrión humano no sería nada más que um producto semejante a uma frambuesa o um renacuajo no tiene em cuenta que em el embrión humano existe la plena potencialidad del hombre". KAUFMANN, Arthur. Filosofía del derecho. Trad. Luis Villar Borda, Ana María Montoya. Universidad Externado de Colombia: Bogotá, 1999, p. 546.

${ }^{59}$ BARROSO, Luís Roberto. Ação Direta de Inconstitucionalidade n. 3.510: pedido de ingresso como amicus curiae formulado por Movitae - Movimento em prol da vida em defesa das pesquisas com células-tronco
} 
O eminente ministro do Supremo Tribunal Federal aponta os estágios de desenvolvimento pelo qual o embrião pré-implantatório não alcançou, de forma a não gozar de dignidade suficiente que exija tutela por parte de uma imposição constitucional, não havendo óbice em sua destruição para fins de pesquisa com células-tronco. Ainda mais porque, como enfatiza Claus Roxin, os embriões in vitro sobrantes de técnicas de reprodução assistida podem contribuir para a humanidade, por meio de pesquisas que visem à cura e à terapia de doenças que acabam por violar a vida digna de seus portadores, concluindo que "quien rechace esta posibilidad no ayuda a la protección de la vida, sino que la daña" ${ }^{60}$. Resta clara a justiça promovida pelo art. $5^{\circ}$, da Lei de Biossegurança, ao permitir um destino louvável aos embriões pré-implantatórios sobrantes.

Entretanto, Roxin rejeita a possibilidade de criação de embriões pré-implantatórios que sirvam, de forma imediata, à pesquisa e à terapia. No mesmo sentido, Maluf adverte que tal atividade seria contrária à moral, aos princípios constitucionais (direito à vida e dignidade da pessoa humana) e feriria os direitos personalíssimos do embrião. ${ }^{61}$ Apreende-se que, mesmo os que se opõem à proibição da pesquisa com embriões pré-implantatórios encontram em sua criação preordenada com o fim de exclusivo de servirem de material para o desenvolvimento médico-científico uma afronta ética e à dignidade da pessoa humana.

É que se argumenta que, no caso de embriões excedentes de técnicas de fertilização in vitro, haveria somente uma destinação daqueles embriões não utilizados, mas produzidos para fins de reprodução. A distinção ética ocorreria, dessa forma, dado à sua finalidade inicial: enquanto o objetivo de reprodução seria legítimo, o de promover a pesquisa não o seria, pois "coisificaria", "instrumentalizaria" o ser humano. ${ }^{62}$

Tal linha de pensamento não assiste razão: tanto a reprodução quanto a pesquisa com escopo terapêutico visam a um bem que justifica a destruição do embrião pré-implantatório. Criá-lo em laboratório voltando-se à promoção e ao aperfeiçoamento de tratamentos e curas para males não desvirtua o respeito à vida do ser humano - que, nesse caso, ressalta-se que

embrionárias (constitucionalidade do art. $5^{\circ}$ da lei n. 11.105/2005). Boletim Científico da Escola Superior do Ministério Público da União, Brasília, v. 5, 18/19, p. 25-55., jan./jul. 2006, p. 43.

${ }^{60}$ ROXIN, Claus. La protección de la vida humana mediante el derecho penal. In: BARJA DE QUIROGA, Jacobo López; ZUGALDÍA ESPINAR, José Miguel (Coords.). Dogmática y ley penal: libro homenaje a Enrique Bacigalupo. Madrid: Marcial Pons, 2004, p. 26.

${ }^{61}$ MALUF, Adriana Caldas do Rego Freitas Dabus. Curso de bioética e biodireito. 3. ed. São Paulo: Atlas, 2015, p. 178.

${ }^{62}$ Ou seja, não se discute a questão da destruição do embrião pré-implantatório, dado que, seja sobrante ou não, ao servir como material para pesquisa, ele será eliminado de uma forma ou de outra. 
não é pessoa, não tem estatuto moral -, ao contrário, fomenta a dignidade da pessoa humana à medida que propicia uma possibilidade de vida mais digna àqueles que sofrem de terríveis doenças. ${ }^{63}$

Adverte-se quanto à possibilidade de descartar as bases teóricas do genéticodesenvolvimentismo sem se furtar encontrar as mesmas conclusões. É como se expressa a justificação de Luigi Ferrajoli, que rejeita um tal direito do embrião a nascer ou de uma ontológica intangibilidade do embrião e, sob uma perspectiva liberal e em uma moral laica fundada na autonomia da consciência, admite que os fins terapêuticos legitimem pesquisas e até a criação de embriões. ${ }^{64}$ Isso porque seria injustificável a tutela enquanto pessoa "de um ente que por si só não é e nem será uma pessoa, não podendo sozinho ser capaz de nascer”, considerando o ato moral de vontade da mãe, de caráter criativo, constitutivo ou performativo da personalidade, com capacidade, só aí, de realizar a exigibilidade da tutela do embrião destinado a nascer e a, portanto, tornar-se pessoa. ${ }^{65}$

Por último, ausente qualquer estatuto moral do embrião in vitro e justificado seu uso em pesquisas com finalidades terapêuticas, a revogação das condições do art. $5^{\circ}$, I e II, da Lei n. 11.105/2005 se impõe. Isto é, não há razão para distinguir, por critérios biológicos (viabilidade) ou temporais, quais embriões pré-implantatórios podem servir como material. Se se permite sua criação com a finalidade exclusiva de terapia, por consequência, qualquer embrião ex utero sobrante, desde que com a anuência dos genitores, poderia ser destinado à pesquisa.

\section{AÇÃO DIRETA DE INCONSTITUCIONALIDADE 3.510: A DECISÃO DO SUPREMO TRIBUNAL FEDERAL QUANTO AO USO DE CÉLULAS-TRONCO EMBRIONÁRIAS}

Sensível à polêmica quanto à permissão do uso de células-tronco embrionárias para fins de pesquisa e terapia, o então procurador-geral da República, Cláudio Lemos Fonteles, ajuizou a Ação Direta de Inconstitucionalidade 3.510, impugnando o art. $5^{\circ}$ da Lei $n$.

\footnotetext{
${ }^{63}$ CARVAlHO, Gisele Mendes de. Patrimônio genético e direito penal. Curitiba, Juruá, 2008, p. 187. No mesmo sentido, posiciona-se Michael Sandel. SANDEL, Michael J. Contra a perfeição: ética na era da engenharia genética. Tradução Ana Carolina Mesquita. Rio de Janeiro: Civilização Brasileira, 2013, p. 118.

${ }^{64}$ FERRAJOLI, Luigi. A questão do embrião entre direito e moral. Revista do Ministério Público de Lisboa, Lisboa, v. 24, n. 94, p. 9-30, abr./jun.. 2003, p. 28.

${ }^{65}$ Ibidem, p. 26-28. Ou, de outra forma: Ferrajoli condiciona o merecimento de tutela somente se e quando o embrião for pensado e desejado como pessoa pela mãe. Ibidem, p. 15.
} 
11.105/2005. Alegando violação ao art. $5^{\circ}$, caput, e ao art. $1^{\circ}$, III, da Constituição Federal de 1988, o chefe do Ministério Público Federal afirmou que

a vida humana surge com a fecundação; que o zigoto é um ser humano embrionário; que é no momento da fecundação que a mulher engravida; e que a pesquisa com células-tronco adultas é mais promissora do que a pesquisa com células-tronco embrionárias. ${ }^{66}$

O Supremo Tribunal Federal julgou, por maioria dos votos $(6 \times 5)$, o pedido integralmente improcedente - cinco ministros seguiram o voto do relator, ministro Ayres Britto, enquanto quatro seguiram o voto divergente do ministro Menezes Direito. ${ }^{67}$ Cabe, portanto, realizar uma breve análise, primeiro, dos principais argumentos do ministro divergente e, em seguida, do ministro relator.

O ministro Menezes Direito baseou sua argumentação na verificação da existência de vida humana no embrião pré-implantatório: seria necessário, portanto, firmar uma compreensão quanto ao início da vida ${ }^{68}$ Caso o início da vida começasse com a fecundação, sua destruição significaria a constatação da violação de seu direito à vida, levando-se à procedência do pedido da ADI 3.510 e à declaração de inconstitucionalidade do art. $5^{\circ}$ da Lei n. $11.105 / 2005$.

Ato contínuo, o ministro rejeita a tese de distinção axiológica conforme etapas de evolução biológica da vida humana - ou seja, firmar um marco seria arbitrário, de forma que se há vida, há dignidade. ${ }^{69}$ Reconhece, portanto, o embrião pré-implantatório, desde a fecundação, como indivíduo, em razão de possuir carga genética individualizada e completa. ${ }^{70}$ O ministro conclui pela procedência parcial dos pedidos, de forma que:

(i) seja entendido que as células-tronco embrionárias somente possam ser obtidas sem a destruição do embrião, com a exceção do previsto no item iii; (ii) seja vedado o descarte de embriões, independentemente de sua viabilidade, morfologia ou qualquer outro critério de classificação; (iii) sejam considerados inviáveis apenas os embriões insubsistentes por si mesmos, ou seja, aqueles que tiveram seu desenvolvimento interrompido por falta espontânea de clivagem após período

\footnotetext{
${ }^{66}$ SOUZA, Paulo Vinicius Sporleder de; CEOLIN, Guilherme; ALBRECHT, Diego. Dignidade da pessoa humana, pesquisa com células-tronco e proteção jurídico-penal do embrião in vitro. D'ÁVILA, Fábio Roberto et al (Org). Direito Penal e Constituição: diálogos entre Brasil e Portugal. Porto Alegre: Boutique Jurídica, 2018, p. 330.

${ }^{67}$ Ibidem, p. 331.

${ }^{68}$ BRASIL. SUPREMO TRIBUNAL FEDERAL. Constitucional. Ação Direta de Inconstitucionalidade 3.510. Lei de Biossegurança. Impugnação em bloco do art. 5º da Lei n. 11.105/2005, de 24 de março de 2005 (Lei de Biossegurança). Lex: jurisprudência do Supremo Tribunal Federal, maio 2008, p. 255.

${ }^{69}$ Ibidem, p. 280.

${ }^{70}$ Ibidem, p. 277.
} 
mínimo superior a vinte e quatro horas, em relação aos quais não haveria qualquer restrição de método para obtenção das células-tronco. ${ }^{71}$

Por outro lado, o relator, ministro Ayres Britto, enfrenta a questão do status moral do embrião humano pré-implantatório, vinculando-se a uma concepção de vida que leva em conta uma dimensão biográfica, e não limitada à biológica, distinguindo-se as etapas de desenvolvimento biológico, referindo-se não a pessoa humana embrionária, mas um embrião de pessoa humana. ${ }^{72}$ Além disso, assevera que o embrião ex utero, diferentemente do embrião in utero, resta refém de condições externas que impedem sua progressão reprodutiva, não havendo de se falar em uma interrupção do processo de formação de uma pessoa, ainda mais porque aquele não alcançara sequer a nidação. ${ }^{73}$

$\mathrm{Na}$ ementa, o relator argumenta que, ao invés de constituir uma afronta à dignidade da pessoa, as pesquisas com células-tronco embrionárias voltadas à pesquisa e à terapia a promovem horizontes positivos para o tratamento e a cura de patologias que atingem as pessoas. Dessa forma, a Constituição acolhe seu uso, adequando-se aos valores de uma sociedade fraterna e solidária e que objetiva a valorização da vida, da saúde e do bem-estar humano

Por último, o ministro ampara-se no direito à liberdade de expressão e de investigação científica (art. $\left.5^{\circ}, \mathrm{IX}, \mathrm{CF}\right)$, no direito à saúde (art. $6^{\circ}$, caput, $\mathrm{CF}$ ) e no livre planejamento familiar (art. 226, $\left.\S 7^{\circ}, \mathrm{CF}\right)^{74}$ a fim de destacar a improcedência do pedido de impugnação do art. $5^{\circ}$ da Lei de Biossegurança, em razão de que a pesquisa com células-tronco embrionárias encontra-se assegurada, por um lado, quanto à atividade em si, com base na liberdade de

\footnotetext{
${ }^{71}$ SOUZA, Paulo Vinicius Sporleder de; CEOLIN, Guilherme; ALBRECHT, Diego. Dignidade da pessoa humana, pesquisa com células-tronco e proteção jurídico-penal do embrião in vitro. D’ÁVILA, Fábio Roberto et al (Org). Direito Penal e Constituição: diálogos entre Brasil e Portugal. Porto Alegre: Boutique Jurídica, 2018, p. 345.

${ }^{72}$ BRASIL. SUPREMO TRIBUNAL FEDERAL. Constitucional. Ação Direta de Inconstitucionalidade 3.510. Lei de Biossegurança. Impugnação em bloco do art. $5^{\circ}$, da Lei n. 11.105/2005, de 24 de março de 2005 (Lei de Biossegurança). Lex: jurisprudência do Supremo Tribunal Federal, maio 2008, p. 165.

${ }^{73}$ Ibidem, p. 179. Nesse sentido, Ingo Sarlet aponta que "se o embrião humano de que trata o art. $5^{\circ}$ da Lei de Biossegurança é um ente absolutamente incapaz de qualquer resquício de vida encefálica, a afirmação de incompatibilidade daquele diploma legal com a Constituição haveria então de ser afastada, conforme o entendimento majoritário formado no STF quando do julgamento da ADIn 3.510". SARLET, Ingo Wolfgang; MARINONI, Luiz Guilherme; MITIDIERO, Daniel. Curso de direito constitucional. 2 ed. São Paulo: Revista dos Tribunais, 2013, p. 370.

74 BRASIL. Constituição da República Federativa do Brasil, de 1988. Disponível em <http://www.planalto.gov.br/ccivil_03/constituicao/constituicao.htm〉. Acesso em: 18 mar. 2021.
} 
investigação e de planejamento familiar, e, por outro, quanto a seu fim, conforme o direito à saúde. $^{75}$

Dadas as conclusões ora apresentadas neste artigo, quando da análise da compatibilidade entre as pesquisas com células-tronco embrionárias e o direito à vida e a dignidade da pessoa humana mediante o método ontoaxiológico, resta afirmar louvável e acertada a decisão do Supremo Tribunal Federal ao declarar a improcedente o pedido da ADI 3.510 .

\section{CONCLUSÃO}

Enfrentou-se, neste artigo, a polêmica em torno da liberação das pesquisas que utilizam células-tronco embrionárias com fins de pesquisa e de terapia a partir da promulgação da Lei n. 11.105/2005. Duas correntes, de forma geral, formaram-se: uma que alega a inconstitucionalidade do art. $5^{\circ}$ da referida Lei e outra que defende não haver qualquer incompatibilidade entre a permissão e a Constituição Federal de 1988.

A primeira posição baseia-se em duas concepções distintas: por um lado, encara-se o embrião pré-implantatório como pessoa desde a fecundação, em que há vida humana com um código genético individualizado e distinto de todos os outros; por outro, com base em uma concepção ética, o embrião pré-implantatório deveria ser considerado pessoa em potencial, assegurando-se seu direito à vida.

A segunda posição se justifica com fulcro em uma análise ontoaxiológica, distinguindo fases biológicas no desenvolvimento do ser humano, impondo distintos graus de proteção. A teoria genético-desenvolvimentista, logo, define a nidação como o momento em que o embrião alcança um status moral; ou seja, o embrião in vitro carece de suficiente dignidade, enquanto meramente pertencente da espécie Homo sapiens, não se configurando como pessoa.

Inexistente um estatuto moral que proteja o embrião pré-implantatório, perfeitamente compatível com a dignidade da pessoa humana e com os direitos e garantias fundamentais da Constituição Federal o disposto no art. $5^{\circ}$, da Lei de Biossegurança. Entretanto, não haveria razão para impor condições quanto à escolha de quais embriões pré-implantatórios a serem destinados à pesquisa e à terapia. Nesse sentido, até mesmo a criação de embriões in vitro

\footnotetext{
${ }^{75}$ BRASIL. SUPREMO TRIBUNAL FEDERAL. Constitucional. Ação Direta de Inconstitucionalidade 3.510. Lei de Biossegurança. Impugnação em bloco do art. $5^{\circ}$, da Lei n. 11.105/2005, de 24 de março de 2005 (Lei de Biossegurança). Lex: jurisprudência do Supremo Tribunal Federal, maio 2008, p. 5-7.
} 
para fins exclusivamente científicos não afronta a valorização da vida humana, devendo ser, assim, igualmente permitida.

O embrião pré-implantatório, entretanto, não se classifica nem como coisa, nem como um nada jurídico - ainda se trata de um ser humano, que exige respeito e valorização. Sua destruição para fins legítimos - i. e., científicos, médicos e reprodutivos - adequa-se ao devido respeito e à dignidade da pessoa humana, promovendo um bem à pessoa humana. $\mathrm{O}$ mesmo não se afirma quanto a sua destinação para fins comerciais, cosméticos e bélicos, que devem ser veementemente rejeitados. Basta, para a promoção integral da dignidade da pessoa humana, uma dura regularização das atividades de pesquisa, que não permita práticas degradantes com os embriões pré-implantatórios.

Nesse sentido julgou o Supremo Tribunal Federal, em sede de decisão acerca da Ação Direta de Inconstitucionalidade 3.150, que impugnou o art. $5^{\circ}$ da Lei de Biossegurança, alegando ofensa ao direito à vida e à dignidade da pessoa humana. $\mathrm{O}$ ministro relator, Ayres Britto, seguido por maioria dos ministros, julgou improcedente o pedido, optando por uma distinção axiológica mediante as fases evolutivas do ser humano e enfatizando, por fim, a promoção da dignidade da pessoa humana por meio de pesquisas com fins de terapia, a liberdade de expressão científica, o direito à saúde, a liberdade do planejamento familiar.

\section{REFERÊNCIAS}

BARROSO, Luís Roberto. Ação Direta de Inconstitucionalidade n. 3.510: pedido de ingresso como amicus curiae formulado por Movitae - Movimento em prol da vida em defesa das pesquisas com células-tronco embrionárias (constitucionalidade do art. $5^{\circ}$ da lei $\mathrm{n}$. 11.105/2005). Boletim Científico da Escola Superior do Ministério Público da União, Brasília, v. 5, 18/19, p. 25-55., jan./jul. 2006.

BECHARA, Ana Elisa Liberatore Silva. Manipulação genética humana e direito penal. Porto Alegre: Zouk, 2007.

BECHARA, Evanildo. Moderna gramática portuguesa. 38 ed. rev. ampl. Rio de Janeiro: Nova Fronteira, 2015.

BITENCOURT, Cezar Roberto. Tratado de direito penal: parte especial 2: crimes contra a pessoa. 17. ed. rev., ampl. e atual. São Paulo: Saraiva, 2017.

BRASIL. Constituição da República Federativa do Brasil, de 1988. Disponível em <http://www.planalto.gov.br/ccivil_03/constituicao/constituicao.htm>. Acesso em: 18 mar. 2021. 
BRASIL. Decreto-Lei n. 2.848, de 07 de dezembro de 1940. Código Penal. Disponível em: < http://www.planalto.gov.br/ccivil_03/decreto-lei/del2848compilado.htm>. Acesso em: 18 mar. 2021.

BRASIL. Lei n. 11.105, de 24 de março de 2005. Lei de Biossegurança. Disponível em: < http://www.planalto.gov.br/ccivil_03/_ato2004-2006/2005/lei/111105.htm>. Acesso em: 18 mar. 2021.

BRASIL. SUPREMO TRIBUNAL FEDERAL. Constitucional. Ação Direta de Inconstitucionalidade 3.510. Lei de Biossegurança. Impugnação em bloco do art. $5^{\circ}$, da Lei n. 11.105/2005, de 24 de março de 2005 (Lei de Biossegurança). Lex: jurisprudência do Supremo Tribunal Federal, Brasília, maio 2008.

CARVALHO, Gisele Mendes de. Patrimônio genético e direito penal. Curitiba, Juruá, 2008.

CORTE INTERAMERICANA DE DERECHOS HUMANOS. Caso Artavia Murillo y otros (Fecundación in vitro) Vs. Costa Rica, p. 264. Sentença de 28 de novembro de 2012. Disponível em http://www.corteidh.or.cr/docs/casos/articulos/seriec_257_por.pdf, acesso em 30 de setembro de 2019.

DINIZ, Maria Helena. O estado atual do biodireito. 10. ed. São Paulo: Saraiva, 2017.

DURAND, Guy. Introdução geral à bioética: história, conceitos e instrumentos. Tradução de Nicolás Nyimi Campanário. 5 ed. São Paulo: Centro Universitário São Camilo, Loyola, 2014.

ESER, Albin. Genética humana: aspectos jurídicos e sociopolíticos. Tradução de Pedro Caeiro. Revista Portuguesa de Ciência Criminal. Lisboa, ano 2., n. 1, p. 45-72, 1992.

FERRAJOLI, Luigi. A questão do embrião entre direito e moral. Revista do Ministério Público de Lisboa, Lisboa, v. 24, n. 94, p. 9-30, abr./jun.. 2003.

KAUFMANN, Arthur. Filosofía del derecho. Trad. Luis Villar Borda, Ana María Montoya. Universidad Externado de Colombia: Bogotá, 1999.

MALUF, Adriana Caldas do Rego Freitas Dabus. Curso de bioética e biodireito. 3. ed. São Paulo: Atlas, 2015.

MANTOVANI, Ferrando. Manipulaciones genéticas, bienes jurídicos amenazados, sistemas de control y técnicas de tutela. Revista de derecho y genoma humano, Bilbao, n. 1, p. 93-119., jul./dez. 1994.

MARTINELLI, João Paulo Orsini; DE BEM, Leonardo Schmitt. Lições fundamentais de direito penal: parte geral. 4. ed. São Paulo: Saraiva, 2019.

MARTÍNEZ, Stella Maris. Ingeniería genética: el desafio actual de la bioética. Cuadernos de bioética, Buenos Aires, v. 1, n. 0, p. 79-86., out, 1996.

MARTÍNEZ, Stella Maris. Manipulação genética e direito penal. São Paulo: IBCCRIM / Complexo Jurídico Damásio de Jesus, 1998. v. 6. 300 p. (Monografias / IBCCRIM, 6).

MENDES, Gilmar Ferreira; BRANCO, Paulo Gustavo Gonet. Curso de direito constitucional. 9. ed. rev. e atual. São Paulo: Saraiva, 2014. 
MUKHERJEE, Siddhartha. $O$ gene: uma história íntima. Tradução: Laura Teixeira Motta. São Paulo: Companhia das Letras, 2016.

PRADO, Luiz Regis; CARVALHO, Érika Mendes de; CARVALHO, Gisele Mendes de. Curso de direito penal brasileiro. 14. ed. rev. atual. e ampl. São Paulo: Revista dos Tribunais, 2015.

PRADO, Luiz Régis. Direito penal do ambiente: crimes ambientais (Lei 9.605/1998). 7. ed.. Rio de Janeiro: Forense, 2019.

RIVA, Léia Comar; BATISTA, Claudia Karina Ladeia; BREVIGLIERI, Etiene Maria Bosco. Os direitos fundamentais do embrião in vitro no Brasil: personalidade e herança. Status Libertatis, Paranaíba, v. 2, n. 2, p. 49-68, 2018.

ROMEO CASABONA, Carlos María. Do gene ao direito: sobre as implicações jurídicas do conhecimento e intervenção no genoma humano. São Paulo: IBCCRIM - Instituto Brasileiro de Ciências Criminais, 1999. v. 9.

ROXIN, Claus. La protección de la vida humana mediante el derecho penal. In: BARJA DE QUIROGA, Jacobo López; ZUGALDÍA ESPINAR, José Miguel (Coords.). Dogmática y ley penal: libro homenaje a Enrique Bacigalupo. Madrid: Marcial Pons, 2004.

SANDEL, Michael J. Contra a perfeição: ética na era da engenharia genética. Tradução Ana Carolina Mesquita. Rio de Janeiro: Civilização Brasileira, 2013.

SARLET, Ingo Wolfgang. Dignidade da pessoa humana e Direitos Fundamentais na Constituição de 1988. 9. ed. Porto Alegre: Livraria do Advogado, 2011.

SARLET, Ingo Wolfgang; MARINONI, Luiz Guilherme; MITIDIERO, Daniel. Curso de direito constitucional. 2 ed. São Paulo: Revista dos Tribunais, 2013.

SILVA, José Afonso. Curso de direito constitucional positivo. 40. ed., rev. e atual. São Paulo: Malheiros, 2017.

SINGER, Peter. Ética prática. Tradução de Jefferson Luiz Camargo. $3^{\circ}$ ed. São Paulo: Martins Fontes, 2002.

SOUZA, Paulo Vinicius Sporleder de; CEOLIN, Guilherme; ALBRECHT, Diego. Dignidade da pessoa humana, pesquisa com células-tronco e proteção jurídico-penal do embrião in vitro. D’ÁVILA, Fábio Roberto et al (Org). Direito Penal e Constituição: diálogos entre Brasil e Portugal. Porto Alegre: Boutique Jurídica, 2018.

SOUZA, Paulo Vinicius Sporleder de. Bem jurídico penal e engenharia genética humana: contributo para compreensão dos bens jurídicos supra-individuais. São Paulo: Revista dos Tribunais, 2004.

SOUZA, Paulo Vinicius Sporleder de. Direito penal genético e a lei de biossegurança: Lei 11.105/2005: comentários sobre crimes envolvendo engenharia genética, clonagem, reprodução assistida, análise genômica e outras questões. Porto Alegre: Livraria do Advogado, 2007. 
VIEIRA, Oscar Vilhena; ALMEIDA, Eloísa Machado de. Constitucionalidade das pesquisas com células-tronco embrionárias. Revista da Defensoria Pública, São Paulo, v. 2, n. 1, p. 257 263., jul./dez. 2008.

\section{DADOS DA PUBLICAÇÃO}

Categoria: artigo submetido ao double-blind review.

Recebido em: 22/03/2021.

Aceito em: 12/12/2021. 